\title{
EKSPLORASI MINAT BEKERJA, BERWIRAUSAHA, DAN MELANJUTKAN STUDI MAHASISWA PROGRAM STUDI TEKNIK MESIN UPI
}

\author{
Ramdan A. Permana1, Tatang Permana ${ }^{2}$, Asep H. Sasmita ${ }^{3}$ \\ Universitas Pendidikan Indonesia \\ Jl. Dr. Setiabudhi No. 229 Bandung 40154 \\ ramdanajipermana@gmail.com
}

\begin{abstract}
ABSTRAK
Penelitian ini bertujuan untuk mengeksplorasi gambaran minat bekerja, berwirausaha, dan melanjutkan studi pada mahasiswa Program Studi D3 Teknik Mesin DPTM FPTK UPI. Berdasarkan hasil penelitian awal ditemukan bahwa mahasiswa cenderung berminat untuk melanjutkan studi. Hal tersebut kurang sejalan dengan tujuan dari pendidikan vokasi. Metode yang digunakan dalam penelitian ini adalah metode deskriptif dengan pendekatan kuantitatif. Penelitian ini dilakukan terhadap 100 responden pada mahasiswa Program Studi Teknik Mesin D3 DPTM FPTK UPI yaitu angkatan 2014, angkatan 2015, dan angkatan 2016. Teknik pengumpulan data dalam penelitian ini menggunakan angket tertutup dengan menggunakan skala Likert. Hasil dari penelitian ini yaitu mahasiswa yang berminat untuk bekerja kurang dari setengahnya, dengan distribusi memilih bekerja di industri produksi yaitu kurang dari setengahnya, di industri otomotif yaitu kurang dari setengahnya, di perusahaan pemerintah/BUMN yaitu sebagian kecil, dan menjadi TNI/Polri yaitu sebagian kecil. Mahasiswa yang berminat untuk berwirausaha yaitu kurang dari setengahnya, dengan distribusi memilih berwirausaha di perbengkelan otomotif yaitu kurang dari setengahnya, di perbengkelan pemesinan seperti las, scraft, bubut, prais, dan CNC yaitu kurang dari setengahnya, di bidang makanan yaitu sebagian kecil, di bidang konveksi yaitu sebagian kecil, dan di bidang pakaian yaitu sebagian kecil. Mahasiswa yang berminat untuk melanjutkan studi yaitu kurang dari setengahnya, dengan distribusi memilih melanjutkan studi ke jenjang pendidikan S1 yaitu lebih dari setengahnya, sedangkan yang memilih untuk melanjutkan studi ke jenjang pendidikan D4 yaitu kurang dari setengahnya.
\end{abstract}

Kata Kunci: minat bekerja, berwirausaha, teknik mesin.

\section{LATAR BELAKANG}

Pendidikan merupakan salah satu wahana untuk mengembangkan kemampuan, membentuk watak serta menambah ilmu pengetahuan untuk mengimbangi perkembangan zaman dan menjawab setiap tantangan global saat ini. Hal tersebut tercantum pada Undang-undang No 20 Tahun 2003 tentang tentang sistem Pendidikan Nasional, Pasal 3 yang menyatakan bahwa: pendidikan nasional berfungsi mengembangkan kemampuan dan membentuk watak serta peradaban bangsa yang bermartabat dalam rangka mencerdaskan kehidupan bangsa, bertujuan untuk berkembangnya potensi peserta didik agar menjadi Marusia yang beriman dan bertakwa kepada Tuhan Yang Maha Esa, berakhlak mulia, sehat, berilmu, cakap, kreatif, mandiri, dan menjadi warga negara yang demokratis serta bertanggung jawab.

\footnotetext{
${ }^{1}$ Mahasiswa Departemen Pendidikan Teknik Mesin FPTK, UPI

2 Dosen Departemen Pendidikan Teknik Mesin FPTK, UPI

${ }^{3}$ Dosen Departemen Pendidikan Teknik Mesin FPTK, UPI
} 
Pendidikan tinggi merupakan salah satu tempat untuk melanjutkan pendidikan dari jenjang pendidikan menengah, diharapkan setelah melanjutkan pendidikan kejenjang yang lebih tinggi bisa meningkatkan kualitas Sumber Daya Manusia (SDM) sehingga bisa mengimbangi perkembangan zaman dan persaingan global tersebut. Pendidikan tinggi mempunyai beberapa jenjang salah satunya yaitu jenjang program diploma, seperti yang tercantum pada Peraturan Pemerintah Nomor 4 tahun 2014 pasal 1 ayat 3 tentang Penyelenggaraan Pendidikan Tinggi dan Pengelolaan Perguruan Tinggi, sebagai berikut: Pendidikan Tinggi adalah jenjang pendidikan setelah pendidikan menengah yang mencakup program diploma, program sarjana, program magister, program doktor, dan program profesi, serta program spesialis, yang diselenggarakan oleh Perguruan Tinggi berdasarkan kebudayaan bangsa Indonesia.

Program diploma yaitu pendidikan vokasi yang dijalankan oleh pendidikan tinggi untuk mempersiapkan peserta belajar agar bisa memiliki pekerjaan dengan keahlian terapan tertentu. Seperti yang dijelaskan oleh UU Sisdiknas No 20 Tahun 2003 Pasal 15 yang menyatakan bahwa: Pendidikan vokasi merupakan pendidikan tinggi yang mempersiapkan peserta belajar untuk memiliki pekerjaan dengan keahlian terapan tertentu maksimal setara dengan program sarjana. Pendidikan vokasi dijalankan oleh perguruan tinggi, seperti politeknik atau sejenis yang memberikan pendidikan melalui jenjang D1, D2, D3 dan D4, hingga SP1 dan SP2 (spesialis yang setara S2 dan S3 atau dengan sebutan magister dan doktor terapan) (Kuswana, 2013).

Sementara itu, penjelasan dari pola sistem pendidikan vokasi dengan jenjang pendidikan program D1, D2, D3 dan D4, hingga SP1 dan SP2, serta lulusan dari program diploma yang diharapkan bisa memiliki pekerjaan dengan keahlian terapan tertentu, tidak sejalan dengan fakta yang ada dilapangan, dari data yang terhimpun oleh Program Studi D3 Teknik Mesin Departemen Pendidikan Teknik Mesin (DPTM) Fakultas Pendidikan Teknologi dan Kejuruan (FPTK) Universitas Pendidikan Indonesia (UPI) dari empat angkatan, yaitu angkatan 2009, 2010, 2011 dan 2012, diperoleh data kurang lebih ada 10\% alumni Program Studi D3 Teknik Mesin DPTM FPTK UPI yang melanjutkan studi ke jenjang pendidikan program sarjana di pendidikan tinggi negeri ataupun pendidikan tinggi swasta, dan dari hasil wawancara awal tentang minat bekerja, berwirausaha, dan melanjutkan studi pada mahasiswa program studi D3 Teknik Mesin D3 DPTM FPTK UPI dengan jumlah mahasiswa 41 orang, terdapat 14 orang berkeinginan untuk bekerja, 7 orang untuk berwirausaha dan 20 Orang menginginkan untuk melanjutkan studi. Data awal minat bekerja, berwirausaha, dan melanjutkan studi pada mahasiswa Program Studi Teknik 
Mesin D3 DPTM FPTK UPI yaitu: bekerja 34,15\%, berwirausaha 17,07\% dan melanjutkan studi $48,78 \%$.

Hasil tersebut menunjukkan bahwa sebagian besar mahasiswa berminat untuk melanjutkan studi dibandingkan untuk bekerja maupun berwirausaha. Minat adalah suatu rasa lebih suka dan rasa ketertarikan pada suatu hal atau aktivitas tanpa ada yang menyuruh. Minat pada dasarnya adalah penerimaan akan suatu hubungan antara diri sendiri dengan dunia luar diri. semakin kuat atau semakin dekat hubungan tersebut semakin besar minat (Slameto, 2013). Minat adalah hasil interaksi pembawaaan dengan lingkungan. Oleh sebab itu, ada orang yang berminat terhadap pekerjaan tertentu karena bakatnya, adapula yang minat karena pengaruh sosial, atau adanya kesempatan yang menimbulkan rasa senang dan puas.

Minat adalah suatu rasa ketertarikan akan sesuatu hal yang dipengaruhi oleh faktor internal dan faktor eksternal tanpa ada yang menyuruh. Minat tidak dibawa sejak lahir, melainkan diperoleh dari hasil interaksi lingkungan sekitar, semakin banyak berinteraksi dan berhubungan dengan lingkungan maka akan timbul minat-minat yang baru. Minat bekerja adalah keinginan seseorang untuk melakukan sebuah kegiatan untuk memperoleh imbalan guna memenuhi kebutuhannya (Schunk, et.al. 2012). Keinginan untuk bekerja yaitu didasari oleh faktor kesadaran sendiri, ekonomi, teman sebaya, mata kuliah yang dipelajari, serta dari kunjungan studi lapangan keberbagai instansi.

Minat berwirausaha adalah keinginan atau ketertarikan seseorang terhadap bidang kewirausahaan yang bersedia untuk bekerja keras dan berani mengambil resiko yang akan terjadi. Mengatur sendiri segala kegiatan yang akan dilakukan, dan wirausahawan harus memiliki kemampuan, keberanian, keteguhan hati, dan kreativitas untuk memulai usahanya tersebut (Uno, 2009). Minat melanjutkan studi adalah keinginan atau ketertarikan seseorang untuk melanjutkan pendidikan yang lebih tinggi sehingga bisa meningkatkan ilmu pengetahuan dan keterampilan yang dimilikinya, yang didasari faktor minat, dukungan sosial, dan efikasi diri.

\section{METODE PENELITIAN}

Penelitian ini menggunakan metode deskriptif. Penelitian ini akan mendeskripsikan minat bekerja, berwirausaha dan melanjutkan studi pada siswa D3 otomotif. Sampel penelitian ini berjumlah mahasiswa 100 orang atau seluruh populasi diteliti. Instrumen yang digunakan pada penelitian ini yaitu angket atau kuesioner. Angket atau kuesioner dibuat dengan pilihan jawaban yang disusun berdasarkan skala Likert. Perhitungan analisis 
data menggunakan persentase. Persentase data digunakan untuk melihat perbandingan besar kecilnya jumlah jawaban yang diberikan responden, karena frekuensi jawaban responden untuk setiap item tidak sama.

\section{HASIL PENELITIAN}

Hasil penelitian diperoleh minat mahasiswa yang paling besar yaitu minat untuk melanjutkan studi sebesar $34.48 \%$, minat untuk bekerja sebanyak $33.78 \%$, dan minat untuk berwirausaha sebanyak $31.74 \%$. Minat mahasiswa yang ingin melanjutkan studi lebih banyak dibandingkan dengan minat bekerja, dan berwirausaha.

\section{PEMBAHASAN}

Mahasiswa mempunyai minat berwirausaha ke jenjang pendidikan S1 lebih besar dibandingkan dengan memilih melanjutkan studi ke jenjang pendidikan D4, dari keseluruhan mahasiswa yang berminat melanjutkan studi. Hasil penelitian diperoleh yang memilih melanjutkan studi ke jenjang pendidikan S1 ada $71.28 \%$. Sedangkan yang memilih untuk melanjutkan studi ke jenjang pendidikan D4 hanya ada $28.72 \%$.

Mahasiswa yang mempunyai minat untuk bekerja ke berbagai bidang, dari keseluruhan yang berminat bekerja yaitu memilih bekerja di industri produksi ada $36.67 \%$, yang berminat untuk bekerja di industri otomotif ada 30\%, yang berminat untuk bekerja di perusahaan pemerintah/BUMN ada $23.33 \%$, dan yang berminat untuk bekerja di TNI/Polri ada 5.56\%. Data tersebut menunjukkan bahwa mahasiswa tidak hanya berminat bekerja sesuai dengan keahlian yang dimilikinya.

Mahasiswa yang mempunyai minat berwirausaha keberbagai bidang, dari keseluruhan yang berminat berwirausaha, yang memilih untuk berwirausaha di perbengkelan otomotif ada $43.75 \%$, yang memilih untuk berwirausaha di bengkel pemesinan seperti las, scraft, bubut, prais, dan $\mathrm{CNC}$ ada $36.25 \%$, yang memilih berwirausaha di bidang makanan ada $12.50 \%$, yang memilih untuk berwirausaha di bidang konveksi ada $6.25 \%$, dan ada mahasiswa yang memilih diluar pemilihan minat berwirausaha yang disediakan yaitu ingin berwirausaha di bidang pakaian yaitu ada $1.25 \%$. Berdasarkan data tersebut dapat dijelaskan bahwa mahasiswa Program Studi Teknik Mesin D3 DPTM FPTK UPI tidak hanya berminat berwirausaha sesuai dengan keahlian yang dimilikinya. 


\section{KESIMPULAN}

Kesimpulan penelitian ini, sebagai berikut: mahasiswa yang berminat untuk bekerja yaitu memilih bidang pekerjaan antara lain: industri produksi industri otomotif perusahaan pemerintah/BUMN, dan PNS/TNI/Polri. Mahasiswa yang berminat untuk berwirausaha dengan jenis usaha sebagai berikut: perbengkelan otomotif, perbengkelan pemesinan seperti las, scraft, bubut, prais, dan CNC, bidang makanan, bidang konveksi bidang dan pakaian. Minat mahasiswa yang berniat melanjutkan studi yaitu ke jenjang pendidikan S1 dan jenjang pendidikan D4.

\section{REFERENSI}

Kuswana, W, S. (2013). Dasar-Dasar Pendidikan Vokasi dan Kejuruan. Bandung: Alfabeta.

Schunk, D. H. et. al. (2012). Motivasi dalam Pendidikan: Teori, Penelitian, dan Aplikasi. Jakarta: PT. Indeks.

Slameto. (2013). Belajar dan Faktor-faktor yang Mempengaruhinya. Jakarta: Rineka Cipta.

Uno, H. B. (2009). Teori Motivasi dan Pengukurannya: Analisis dibidang Pendidikan. Jakarta: Bumi Aksara. 